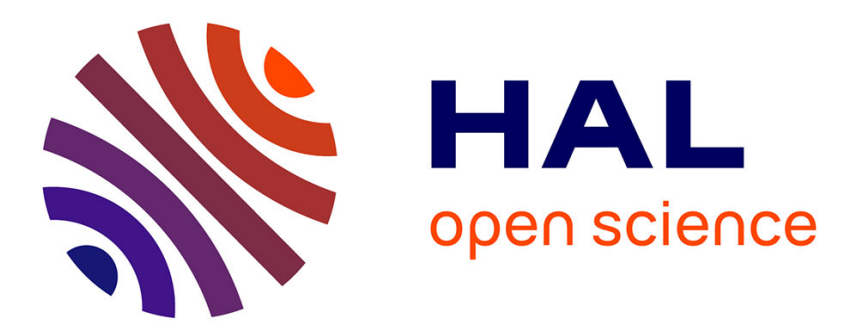

\title{
Maternal oxytocin triggers a transient inhibitory switch in GABA signaling in the fetal brain during delivery.
}

Roman Tyzio, Rosa Cossart, Ilgam Khalilov, Marat Minlebaev, Christian A. Hübner, Alfonso Represa, Yehezkel Ben-Ari, Rustem Khazipov

\section{- To cite this version:}

Roman Tyzio, Rosa Cossart, Ilgam Khalilov, Marat Minlebaev, Christian A. Hübner, et al.. Maternal oxytocin triggers a transient inhibitory switch in GABA signaling in the fetal brain during delivery.. Science, 2006, 314 (5806), pp.1788-92. 10.1126/science.1133212 . inserm-00483930

\section{HAL Id: inserm-00483930 https://www.hal.inserm.fr/inserm-00483930}

Submitted on 17 May 2010

HAL is a multi-disciplinary open access archive for the deposit and dissemination of scientific research documents, whether they are published or not. The documents may come from teaching and research institutions in France or abroad, or from public or private research centers.
L'archive ouverte pluridisciplinaire HAL, est destinée au dépôt et à la diffusion de documents scientifiques de niveau recherche, publiés ou non, émanant des établissements d'enseignement et de recherche français ou étrangers, des laboratoires publics ou privés. 


\title{
Science \\ MIAAAS
}

\author{
Maternal Oxytocin Triggers a Transient Inhibitory \\ Switch in GABA Signaling in the Fetal Brain During \\ Delivery \\ Roman Tyzio, et al. \\ Science 314, 1788 (2006); \\ DOI: $10.1126 /$ science. 1133212
}

The following resources related to this article are available online at www.sciencemag.org (this information is current as of January 16, 2009 ):

Updated information and services, including high-resolution figures, can be found in the online version of this article at:

http://www.sciencemag.org/cgi/content/full/314/5806/1788

Supporting Online Material can be found at:

http://www.sciencemag.org/cgi/content/full/314/5806/1788/DC1

A list of selected additional articles on the Science Web sites related to this article can be found at:

http://www.sciencemag.org/cgi/content/full/314/5806/1788\#related-content

This article cites 31 articles, 13 of which can be accessed for free:

http://www.sciencemag.org/cgi/content/full/314/5806/1788\#otherarticles

This article has been cited by 19 article(s) on the ISI Web of Science.

This article has been cited by 14 articles hosted by HighWire Press; see:

http://www.sciencemag.org/cgi/content/full/314/5806/1788\#otherarticles

This article appears in the following subject collections:

Neuroscience

http://www.sciencemag.org/cgi/collection/neuroscience

Information about obtaining reprints of this article or about obtaining permission to reproduce this article in whole or in part can be found at:

http://www.sciencemag.org/about/permissions.dt 
How is the LPFC activity related to the activity in $\mathrm{MT}+$ in the task-irrelevant condition? The correlation coefficient between the task-irrelevance-related activity (28) in MT+ and the LPFC was -0.90 . This is in accord with the view that when the LPFC is activated, it provides direct or indirect inhibitory control on the activity of MT+.

One might think that the low performance at the $5 \%$ coherence ratio was obtained because, despite the instructions to focus on RSVP task performance, the participants may have tried to find a coherent motion direction or to detect whether coherent motion was presented. If these motion tasks are difficult, they may leave fewer resources available for the RSVP task. However, this is not likely. If the participants engaged in the search for motion direction, this task should be hardest at $0 \%$ coherence and therefore, the lowest RSVP performance should have occurred at $0 \%$ and not at $5 \%$ coherence. Second, if the participants engaged in motion detection, this task should be hardest at $5 \%$ coherence because indecision may be greatest near the coherent motion threshold, and thus in accordance with the observed RSVP performance result. However, the lowest blood oxygen level-dependent (BOLD) activity was observed at 5\% coherence ratio in the LPFC and cannot be directly explained by this possibility.

The results of the present study demonstrate two important points. First, a weak taskirrelevant stimulus feature that is below but near the perceptual threshold more strongly activates the visual area $(\mathrm{MT}+)$ that is highly related to the stimulus feature and more greatly disrupts task performance. There was a tendency for activity in the posterior occipitotemporal sulcus (pOTS) $(29,30)$ and the left angular gyrus $(31)$, which are sensitive to letters and words and may be related to the RSVP task, to be lower at the 5\% coherence than at the other coherent motion ratios. This contradicts the general view that irrelevant signals that are stronger in stimulus properties have a greater influence on the brain and performance and that the influence of a subthreshold stimulus is smaller than that of a suprathreshold stimulus.

Second, the results may reveal important bidirectional interactions between a cognitive controlling system and the visual system. The LPFC, which has been suggested to provide inhibitory control on task-irrelevant signals (22-26), may have a higher detection threshold for incoming signals than the visual cortex. Task-irrelevant signals around the threshold level may be sufficiently strong to be processed in the visual system but not strong enough for the LPFC to notice and, therefore, to provide effective inhibitory control on the signals (Fig. 4A). In this case, such signals may remain uninhibited, take more resources for a taskirrelevant distractor, leave fewer resources for a given task $(32,33)$, and disrupt task performance more than suprathreshold signals. On the other hand, suprathreshold coherent motion may be noticed, may be given successful inhibitory control by the LPFC, and may leave more resources for a task (Fig. 4B) (22-26). This mechanism may underlie the present paradoxical finding that subthreshold task-irrelevant stimuli activate the visual area strongly and disrupt task performance more than some suprathreshold stimuli. It could also be one of the reasons why subthreshold stimuli often lead to relatively robust effects $(2,11,14)$.

\section{References and Notes}

1. S. He, P. Cavanagh, J. Intriligator, Nature 383, 334 (1996).

2. T. Watanabe, J. E. Nanez, Y. Sasaki, Nature 413,844 (2001).

3. J. K. O'Regan, R. A. Rensink, ]. ]. Clark, Nature 398, 34 (1999).

4. A. Mack, I. Rock, Inattentional Blindness (MIT Press, Cambridge, MA, 1998).

5. M. M. Chun, J. Exp. Psychol. Hum. Percept. Perform. 23, 738 (1997).

6. V. Stuphorn, J. D. Schall, Nat. Neurosci. 9, 925 (2006).

7. R. Blake, R. Fox, Nature 249, 488 (1974).

8. S. H. Lee, R. Blake, D. J. Heeger, Nat. Neurosci. 8, 22 (2005).

9. N. K. Logothetis, ]. D. Schall, Science 245, 761 (1989).

10. S. Dehaene et al., Nature 395, 597 (1998).

11. M. Bar, I. Biederman, Psychol. Sci. 9, 464 (1998).

12. J. D. Haynes, G. Rees, Nat. Neurosci. 8, 686 (2005).

13. A. Sahraie, M. Milders, M. Niedeggen, Vision Res. 41, 1613 (2001).

14. A. R. Seitz, T. Watanabe, Nature 422, 36 (2003).

15. M. Niedeggen, A. Sahraie, G. Hesselmann, M. Milders, C. Blakemore, Brain Res. Cogn. Brain Res. 13, 241 (2002).

16. Materials and methods are available as supporting material on Science Online.

17. W. T. Newsome, E. B. Pare, J. Neurosci. 8, 2201 (1988).

18. G. Rees, K. Friston, C. Koch, Nat. Neurosci. 3, 716 (2000).

19. J. Stroop, J. Exp. Psychol. 18, 643 (1935).

20. A. M. Treisman, G. Gelade, Cogn. Psychol. 12, 97 (1980).

21. S. R. Friedman-Hill, L. C. Robertson, R. Desimone, L. G. Ungerleider, Proc. Natl. Acad. Sci. U.S.A. 100, 4263 (2003).

22. R. Dias, T. W. Robbins, A. C. Roberts, Nature 380, 69 (1996).
23. J. M. Fuster, The Prefrontal Cortex: Anatomy, Physiology, and Neurophysiology of the Frontal Lobe (LippincottRaven, New York, ed. 3, 1997).

24. R. T. Knight, W. R. Staines, D. Swick, L. L. Chao, Acta Psychol. (Amst.) 101, 159 (1999).

25. J. G. Kerns et al., Science 303, 1023 (2004).

26. A. W. MacDonald III, ]. D. Cohen, V. A. Stenger, C. S. Carter, Science 288, 1835 (2000).

27 . In the control condition in which motion was taskrelevant (Fig. 3B, green), no significant difference was found between any pair of coherence levels.

28. Task-irrelevance-related activity is defined as a BOLD signal amount in the task-relevant condition subtracted from that in the task-irrelevant condition, for each motion coherence and for each cortical area.

29. M. Ben-Shachar, R. F. Dougherty, G. K. Deutch, B. A. Wandell, Cereb. Cortex 10.1093/cercor/bhl071 (2006).

30. S. Dehaene, L. Cohen, M. Sigman, F. Vinckier, Trends Cogn. Sci. 9, 335 (2005).

31. A. M. Callan, D. E. Callan, S. Masaki, Neuroimage 28, 553 (2005)

32. R. Desimone, ]. Duncan, Annu. Rev. Neurosci. 18, 193 (1995).

33. E. K. Miller, ]. D. Cohen, Annu. Rev. Neurosci. 24, 167 (2001).

34. This study is funded by grants from NIH (R01 EY015980 and R21 EY017737), NSF (BCS-0345746, BCS-0549036, and BCS-PR04-137 Center of Excellence for Learning in Education, Science, and Technology), and the Human Frontier Science Program Organization (RGP18/2004) to T.W., and by grants from National Center for Research Resources (P41RR14075), the Mental Illness and Neuroscience Discovery Institute, the Athinoula A. Martinos Center for Biomedical Imaging, and the ERATO Shimojo Implicit Brain Function project to Y.S. We thank P. Cavanagh, Y. Kamitani, M. Kawato, I. Motoyoshi, ]. Nanez, M. Sakagami, S. Shimojo, and the members of Vision Sciences Laboratory at Boston University for their comments on the study and N. Ito and Y. Yotsumoto for technical assistance.

\section{Supporting Online Material}

www.sciencemag.org/cgi/content/full/314/5806/1786/DC1 Materials and Methods

Figs. S1 and S2

References

31 July 2006; accepted 20 October 2006

10.1126/science. 1133197

\title{
Maternal Oxytocin Triggers a Transient Inhibitory Switch in GABA Signaling in the Fetal Brain During Delivery
}

\author{
Roman Tyzio, ${ }^{1}$ Rosa Cossart, ${ }^{1}$ Ilgam Khalilov, ${ }^{1}$ Marat Minlebaev, ${ }^{1}$ Christian A. Hübner, ${ }^{2}$ \\ Alfonso Represa, ${ }^{1}$ Yehezkel Ben-Ari, ${ }^{1 *}$ Rustem Khazipov ${ }^{1}$
}

We report a signaling mechanism in rats between mother and fetus aimed at preparing fetal neurons for delivery. In immature neurons, $\gamma$-aminobutyric acid (GABA) is the primary excitatory neurotransmitter. We found that, shortly before delivery, there is a transient reduction in the intracellular chloride concentration and an excitatory-to-inhibitory switch of GABA actions. These events were triggered by oxytocin, an essential maternal hormone for labor. In vivo administration of an oxytocin receptor antagonist before delivery prevented the switch of GABA actions in fetal neurons and aggravated the severity of anoxic episodes. Thus, maternal oxytocin inhibits fetal neurons and increases their resistance to insults during delivery.

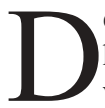

elivery is a stressful event associated with high risks to the fetal brain (1); however, whether the fetal brain prepares for delivery remains largely unknown. We addressed this issue by studying $\gamma$-aminobutyric acid (GABA)-mediated (GABAergic) signaling in the 
rat hippocampus. GABA is the principal inhibitory neurotransmitter in the adult brain. However, during fetal and postnatal periods GABA has a depolarizing action (2-4) and provides the major, and often the only, excitatory synaptic input to immature neurons (5). Excitatory action of GABA is due to elevated intracellular chloride and depolarized value of the GABA type $A\left(G_{A B A}\right)$ reversal potential $\left(E_{\mathrm{GABA}}\right)(6-10)$. Excitatory GABA is pivotal in control of neuronal firing, generation of the primitive patterns of activity, intracellular calcium signaling, and neuronal development $(2,3)$. GABA signaling is therefore expected to be an essential element in physiological adaptation to stress during delivery.

To characterize the properties of GABA signaling during the perinatal period, we used cellattached recordings from fetal and neonatal rat hippocampal slices [from embryonic day (E) 18 to postnatal day (P) 5; term is E21] (11). During fetal (E18 and E19) and postnatal periods (P1 to P5), activation of $\mathrm{GABA}_{\mathrm{A}}$ receptors increased the firing

${ }^{1}$ Institut de Neurobiologie de la Méditerranée, INSERM U29, Université de la Méditerranée, Campus Scientifique de Luminy, Boite Postale 13, 13273 Marseille Cedex 09 France. ${ }^{2}$ Institut für Humangenetik, Universitätsklinikum Hamburg-Eppendorf, 20251 Hamburg, Germany.

*To whom correspondence should be addressed. E-mail: ben-ari@inmed.univ-mrs.fr
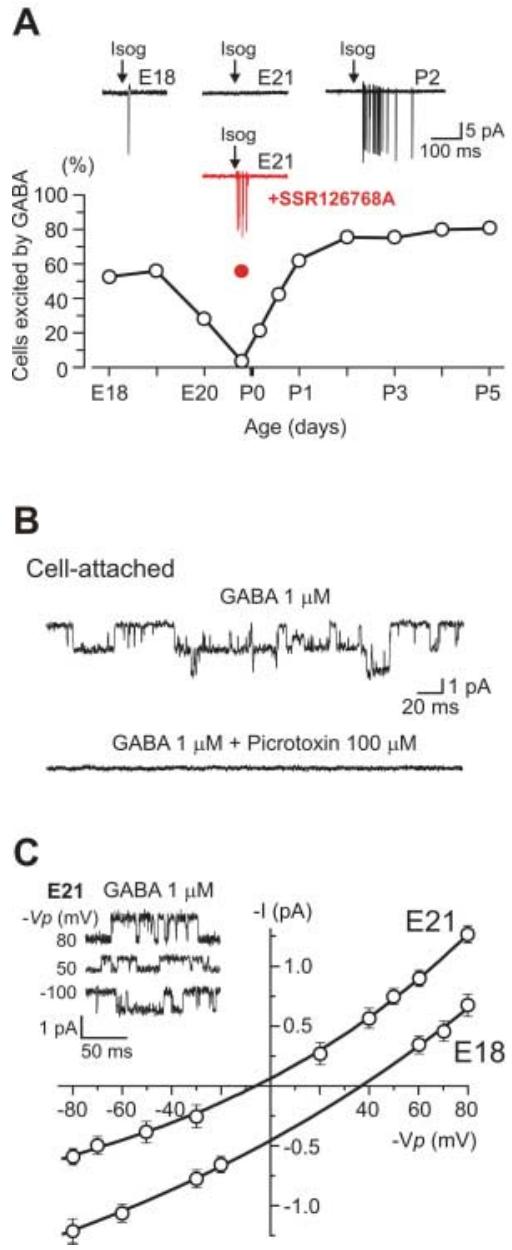

of action potentials in the majority of CA3 pyramidal cells [Fig. 1A; also $(6,7,12)]$. However, during a brief period extending from E20 to day of birth (P0), the proportion of cells excited by GABA sharply decreased. The loss of the excitatory effect of GABA peaked at E21 [ 1 to 2 hours before delivery (Fig. 1A)].

The action of GABA depends on the direction of the transmembrane current elicited by GABA, its driving force $\left(D F_{\mathrm{GABA}}\right)$ being the difference between $E_{\mathrm{GABA}}$ and resting membrane potential $\left(E_{\mathrm{m}}\right)$. Positive values of $D F_{\mathrm{GABA}}$ determine excitatory actions of GABA in immature neurons $(2,3,6,7)$. To estimate $D F_{\mathrm{GABA}}$, we used cellattached recordings of single $\mathrm{GABA}_{\mathrm{A}}$ channels (10) (Fig. 1, B to D), which affect neither $E_{\mathrm{GABA}}$ nor $E_{\mathrm{m}}$. With $1 \mu \mathrm{M}$ GABA in the pipette solution, $\mathrm{GABA}_{\mathrm{A}}$ channels were observed in $\sim 90 \%$ of patches $(n=553)$ but not in the presence of the $\mathrm{GABA}_{\mathrm{A}}$ receptor antagonist picrotoxin $[100 \mu \mathrm{M}$; $n=25$ (Fig. 1B)]. We found that $D F_{\mathrm{GABA}}$ is strongly depolarizing in fetal and postnatal periods (Fig. 1D). However, $D F_{\mathrm{GABA}}$ negatively shifted during a brief near-term period (from E20 to P0), switching to a hyperpolarizing value of $-8.4 \pm$ $2.5 \mathrm{mV}$ at term [mean $\pm \mathrm{SEM}, n=34$ (Fig. 1D)]. Thus, the disappearance of GABA-mediated excitation at term (Fig. 1A) coincides with a switch in polarity of GABA signals.

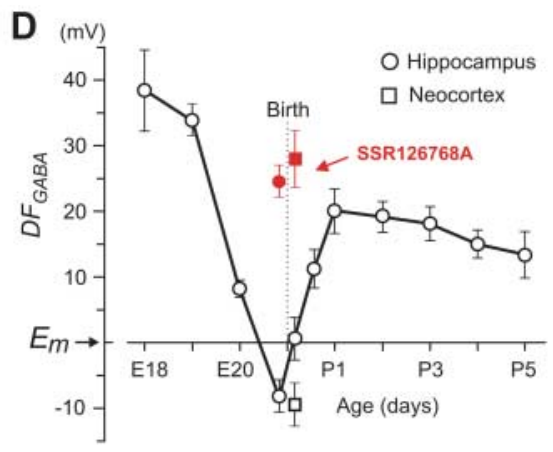

E
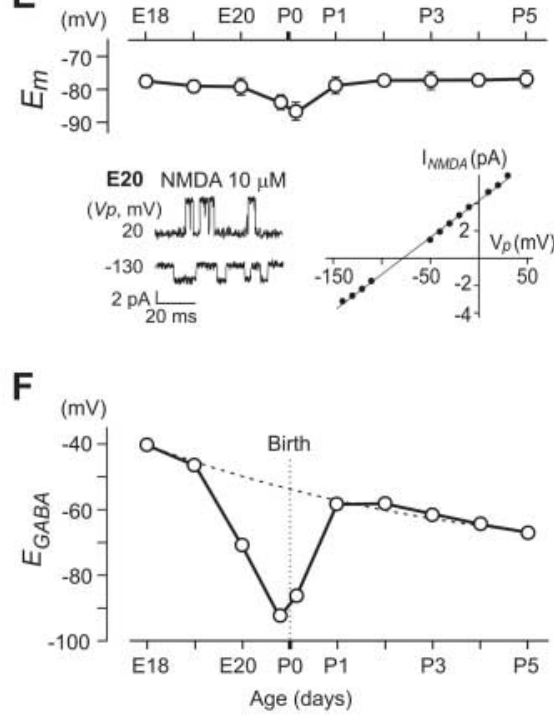

The perinatal changes in $D F_{\mathrm{GABA}}$ could be due to a negative shift of $E_{\mathrm{GABA}}$ or to a depolarizing shift of $E_{\mathrm{m}}$. By using cell-attached recordings of single $N$-methyl-D-aspartate (NMDA) channels as voltage sensors $(12,13)$, we found that during early fetal and postnatal periods $E_{\mathrm{m}}$ is $-78.7 \pm 1.9 \mathrm{mV}$ ( $n=42$; pooled data for E18 and E19 and P1 to P5) [also $(13,14)$ ], but near term there is a small hyperpolarizing shift to $-85.4 \pm 1.5 \mathrm{mV}[n=14$ at birth (Fig. 1E)]. Knowing $D F_{\mathrm{GABA}}$ and $E_{\mathrm{m}}$, we calculated $E_{\mathrm{GABA}}\left(E_{\mathrm{GABA}}=D F_{\mathrm{GABA}}+E_{\mathrm{m}}\right)$ and found that $E_{\mathrm{GABA}}$ switches from $-40 \mathrm{mV}$ at $\mathrm{E} 18$ to $-92 \mathrm{mV}$ at E21 and then returns to depolarizing values shortly after birth (Fig. 1F). This corresponds to a decrease in $\left[\mathrm{Cl}^{-}\right]_{\mathrm{i}}$ (intracellular chloride concentration) from $18 \mathrm{mM}$ to $4 \mathrm{mM}$ (Fig. 1F).

Because GABA-induced depolarization raises $\left[\mathrm{Ca}^{2+}\right]_{i}(12,15-18)$, we used a multibeam two-photon microscope to monitor $\left[\mathrm{Ca}^{2+}\right]_{\mathrm{i}}$ changes in hundreds of CA3 neurons in slices loaded with the calcium indicator fura 2-AM (Fig. 2). The $\mathrm{GABA}_{\mathrm{A}}$ receptor agonist isoguvacine $(10 \mu \mathrm{M})$ elicited a robust increase of $\left[\mathrm{Ca}^{2+}\right]_{i}$ in the majority of neurons at $\mathrm{E} 18$ and at $\mathrm{P} 2$ to $\mathrm{P} 4$ [average of $56 \pm 3 \%, n$ values of 7 movies and 931 cells (Fig. 2, B to D)]. In contrast, at E21 to $\mathrm{P} 0,\left[\mathrm{Ca}^{2+}\right]_{\mathrm{i}}$ increased in only $31 \pm 6 \%$ ( $n$ values of 10 movies and 1546 cells, $P<0.01)$ cells. Isoguvacine also decreased the frequency of spontaneous calcium

Fig. 1. Transient perinatal loss of the $G_{A B A}$ mediated excitation. (A) Responses of CA3 pyramidal cells recorded in cell-attached mode to the $\mathrm{GABA}_{\mathrm{A}}$ agonist isoguvacine. Below, summary plot of the proportion of cells excited by isoguvacine during the perinatal period. There is a transient loss of the excitatory effect of isoguvacine near term. Red corresponds to the fetuses whose mothers received SSR126768A. [E21 corresponds to the early phase of delivery ( 1 to 2 hours before birth); PO is the day of birth; pooled data from 146 neurons.] (B) Cellattached recordings of single $\mathrm{GABA}_{\mathrm{A}}$ channels with $1 \mu M$ of GABA in patch pipette (top trace); the channels were not observed in the presence of the $\mathrm{GABA}_{\mathrm{A}}$ antagonist picrotoxin $(100 \mu \mathrm{M}$; bottom trace). (C) $I-V$ relationships of the currents through $\mathrm{GABA}_{A}$ channels in two cells at E21 and E18; their reversal potential corresponds to $D F_{\mathrm{GABA}}$. (D) Summary plot of the age dependence of $D F_{\mathrm{GABA}}$ inferred from single $\mathrm{GABA}_{\mathrm{A}}$ channels recordings [mean \pm SEM; 209 CA3 pyramidal cells (O) and 17 neocortical pyramidal cells ( $\square) ; 6$ to 24 patches for each point]. Red indicates pretreatment with SSR126768A ( $n$ values are 25 hippocampal and 9 neocortical patches). (E) Age dependence of the resting membrane potential $\left(E_{\mathrm{m}}\right)$ of CA3 pyramidal cells inferred from the reversal of single NMDA channels recorded in cell-attached mode ( $n=84$ cells; 4 to 12 patches for each point). (F) Age dependence of the $G A B A_{A}$ reversal potential $\left(E_{\mathrm{GABA}}=E_{\mathrm{m}}+D F_{\mathrm{GABA}}\right)$. There is a transient hyperpolarizing shift of $E_{\mathrm{GABA}}$ near birth. 
events in many neurons near term $[9 \pm 2 \%$ (Fig. 2)]. Thus, during delivery, the ability of GABA to increase $\left[\mathrm{Ca}^{2+}\right]_{\mathrm{i}}$ is significantly reduced.

What underlies the near-term switch in GABA actions? Because this phenomenon is not observed in fetal neurons grown in culture $(8,9)$, we hypothesized that it is related to parturition and in particular to maternal hormones released during delivery. Parturition is initiated by a massive release of oxytocin (19). In addition to its pivotal role in parturition, there are also indications that oxytocin exerts multiple effects in the adult central nervous system (19-25). Maternal oxytocin easily crosses the placenta to reach the fetus (26), suggesting that oxytocin may be responsible for the hyperpolarizing switch in action of GABA in fetal neurons during delivery. With selective antibodies, we found a high density of oxytocin receptor immunoreactivity in the hippocampus and neocortex during the perinatal period (Fig. 3A and figs. S1 and S2). During cell-attached recordings from slices at E18 and P2, applications of oxytocin $(1 \mu \mathrm{M})$ induced a negative shift in $D F_{\mathrm{GABA}}$ (Fig. 3, C and D) and suppressed GABA-mediated excitation (Fig. 3B). The effects of oxytocin were completely prevented by bath application of the selective oxytocin receptor antagonist atosiban (AT, 1 to $5 \mu \mathrm{M}$ ) (Fig. 3D). At term, application of oxytocin did not cause a significant effect on the hyperpolarizing $D F_{\mathrm{GABA}}$ (Fig. 3D), suggesting that the effects of exogenous oxytocin are occluded by the endogenous hormone. In keeping with this hypothesis, we found that atosiban switched $D F_{\mathrm{GABA}}$ from hyperpolarizing to depolarizing at term but not in

Fig. 2. Perinatal effects of $G A B A_{A}$ receptors activation on $\left[\mathrm{Ca}^{2+}\right]_{i}$ in $C A 3$ neurons. (A) Twophoton $\left[\mathrm{Ca}^{2+}\right]_{i}$ fluorescence image of the CA3 region from a PO hippocampal slice loaded with fura 2-AM; scale bar indicates $100 \mu \mathrm{m}$. (Right) Automatically detected contours of the cells. (B) Three types of $\left[\mathrm{Ca}^{2+}\right]_{i}$ responses $(\Delta F / F)$ to bath application of the $\mathrm{GABA}_{\mathrm{A}}$ agonist isoguvacine $(10 \mu \mathrm{M}$, 1 min): excited (red), inhibited (blue), or not affected (black) by isoguvacine (Isog). (C) Contour maps representing the distribution of different cellular responses to isoguvacine at E18, P0, and P5: excited (red), inhibited (blue), and not affected (open contours). Bottom histograms show the percentage of cells that are detected as being active on each movie frame corresponding to the above contour plots (140 ms per frame). Isoguvacine application $(10 \mu \mathrm{M})$ produces a significant increase in the fraction of active neurons at E18 and P5, whereas it slightly decreased the activity at birth. (D) Histograms of the averaged fraction of imaged neurons excited (top) or inhibited or nonaffected (bottom) by isoguvacine at different ages (for P0, $n$ values of 10 movies and 1546 cells; for E18, $n$ values of 2 movies and 375 cells; and for P5, $n$ values of 3 movies and 328 cells; ${ }^{*} P<0.01$ ). Error bars indicate SEM. fetal and postnatal neurons (Fig. 3D). Moreover, intracardial perfusion of E21 fetuses with artificial cerebrospinal fluid (ACSF, to wash out endogenous hormone) produced a similar shift of $D F_{\mathrm{GABA}}$ from hyperpolarizing to depolarizing (fig. S3). Addition of $1 \mu \mathrm{M}$ oxytocin at the end of the perfusion restored hyperpolarizing values of $D F_{\mathrm{GABA}}$ (fig. S3). Therefore, endogenous oxytocin is present in slices at term and provides tonic activation of oxytocin receptors, leading to the shift of $D F_{\mathrm{GABA}}$. We also found that the negative shift in $D F_{\mathrm{GABA}}$ from $38.4 \pm 6.2 \mathrm{mV}(n=8)$ to $-7.2 \pm 2.2 \mathrm{mV}(n=18)$ occurred in E18 fetuses obtained from mothers treated with oxytocin $(50 \mu \mathrm{g} / \mathrm{kg})$ during 2 hours before cesarean delivery.

To directly measure the effects of oxytocin on $\left[\mathrm{Cl}^{-}\right]_{i}$, we used two-photon chloride imaging in slices loaded with a chloride-sensitive dye, MQAE (Fig. 3, E and F) (27). In E18 and P4 slices, oxytocin $(1 \mu \mathrm{M})$ produced a significant increase in the baseline fluorescence signal in half of the imaged cells, indicating a strong reduction of $\left[\mathrm{Cl}^{-}\right]_{\mathrm{i}}$ [average of $43 \pm 4 \%, n$ values of 10 movies and 1792 cells (Fig. 3F)], and the effect was prevented by atosiban $\left(5 \mu \mathrm{M}\right.$; reduction of $\left[\mathrm{Cl}^{-}\right]_{\mathrm{i}}$ in $5 \pm 3 \%$ cells, $n$ values of 2 movies and 435 cells). Furthermore, incubation of $\mathrm{P} 4$ slices with oxytocin reversed the effect of isoguvacine on spontaneous calcium events $[59 \pm 17 \%$ imaged cells not activated by isoguvacine, $n$ values of 3 movies and 228 cells (fig. S4)]. Thus, the effects of oxytocin fully matched the changes in GABA signaling occurring at term. This result indicates that oxytocin is sufficient to trigger changes of $\left[\mathrm{Cl}^{-}\right]$.
To determine whether endogenous oxytocin is necessary for the near-term switch in the action of GABA, we treated pregnant rats orally with the selective oxytocin receptor antagonist SSR126768A (28) (1 mg/kg, starting from E20) and measured the consequences at term. Cell-attached recordings revealed major differences between treated and age-matched control pups, including strongly depolarizing values of $D F_{\mathrm{GABA}}$ (Fig. 1D, red circle) and a high proportion of cells excited by GABA (Fig. 1A, red circle). Similar effects were also observed in neocortical neurons, in which $D F_{\mathrm{GABA}}$ was $-9.4 \pm 3.4 \mathrm{mV}$ in control rat pups $(n=8)$ and $28.3 \pm 3.7 \mathrm{mV}(n=9)$ in pups of mothers pretreated with SSR126768A (Fig. 1D). Thus, maternal oxytocin is necessary and sufficient to trigger the near-term switch in GABA action in the hippocampus and neocortex.

What are the mechanisms underlying the oxytocin-mediated reduction of $\left[\mathrm{Cl}^{-}\right]_{\mathrm{i}}$ at term? Because the NKCC1 chloride inward cotransporter is responsible for elevated $\left[\mathrm{Cl}^{-}\right]_{\mathrm{i}}$ in immature neurons $(4,7,29,30)$, we tested the effects of the selective NKCC1 antagonist bumetanide. We found that bumetanide $(10 \mu \mathrm{M})$ produces a robust negative shift of $D F_{\mathrm{GABA}}$ and occludes the effects of oxytocin (fig. S5). The short latency of oxytocin actions (Fig. 3F) and the observation that blockade of oxytocin receptors does not alter chloride transporters gene expression (fig. S6) suggest that the hormone down-regulates $\mathrm{NKCCl}$ activity.

Hypoxic-ischemic brain damage is a principal cause of newborn death and neurological impairment (1). We hypothesized that the excitatory-to-
A
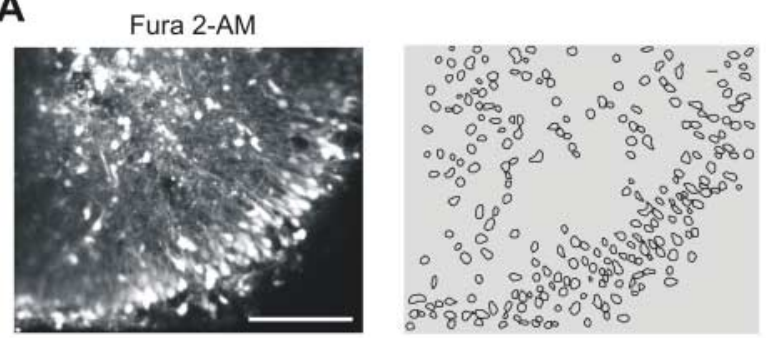

C
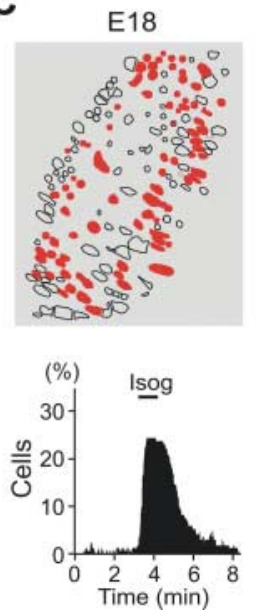
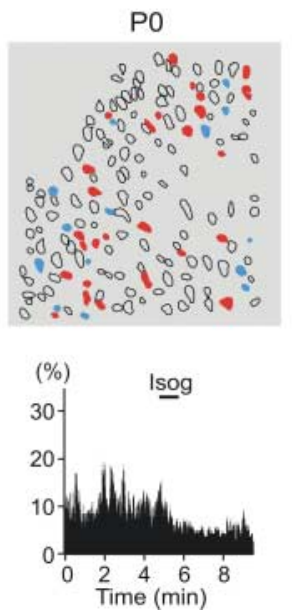

B

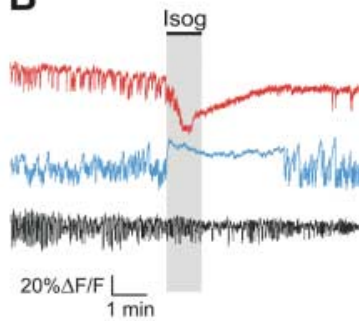

D
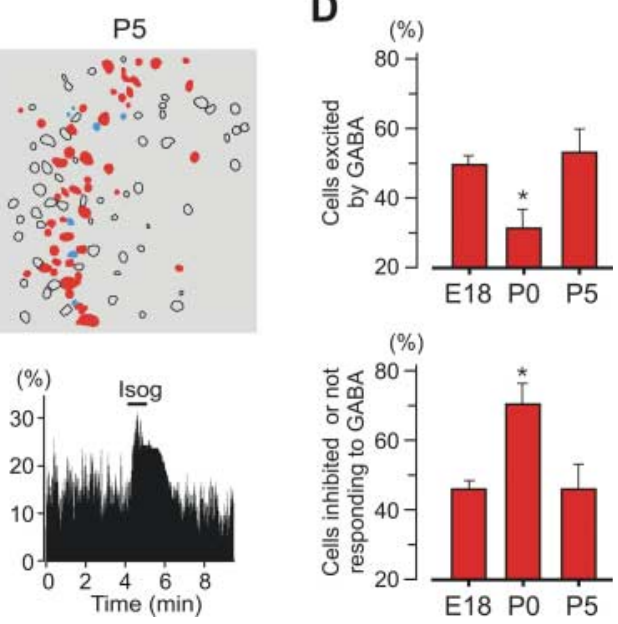
inhibitory switch in GABA signaling reduces neuronal activity and metabolic demand, thus helping to protect fetal neurons from hypoxic insults (31). Episodes of anoxia and aglycemia were induced by superfusion with a solution in which oxygen was substituted for nitrogen and glucose was substituted for sucrose. The onset of anoxic depolarization $(\mathrm{AD})$ that is an electrophysiological

A

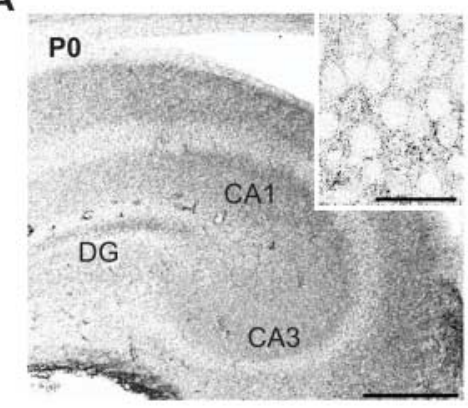

marker of neuronal death $(31,32)$ was measured by using extracellular field potential recordings in the intact hippocampi of E21 rats in vitro after various treatments in vivo to the mother and/or to the fetuses intracardially before the in vitro experiment (Fig 4). In control fetuses, AD occurred after $55.6 \pm$ $1.4 \min (n=30)$ of perfusion with the anoxicaglycemic solution (Fig. 4). In the hippocampi

\section{B}

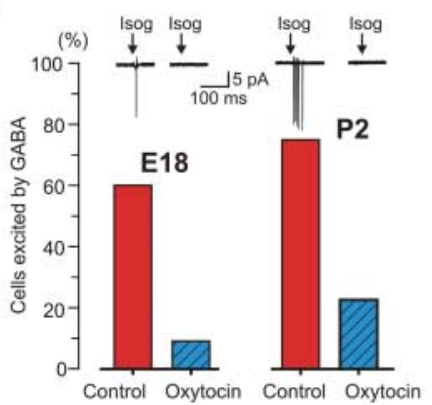

C
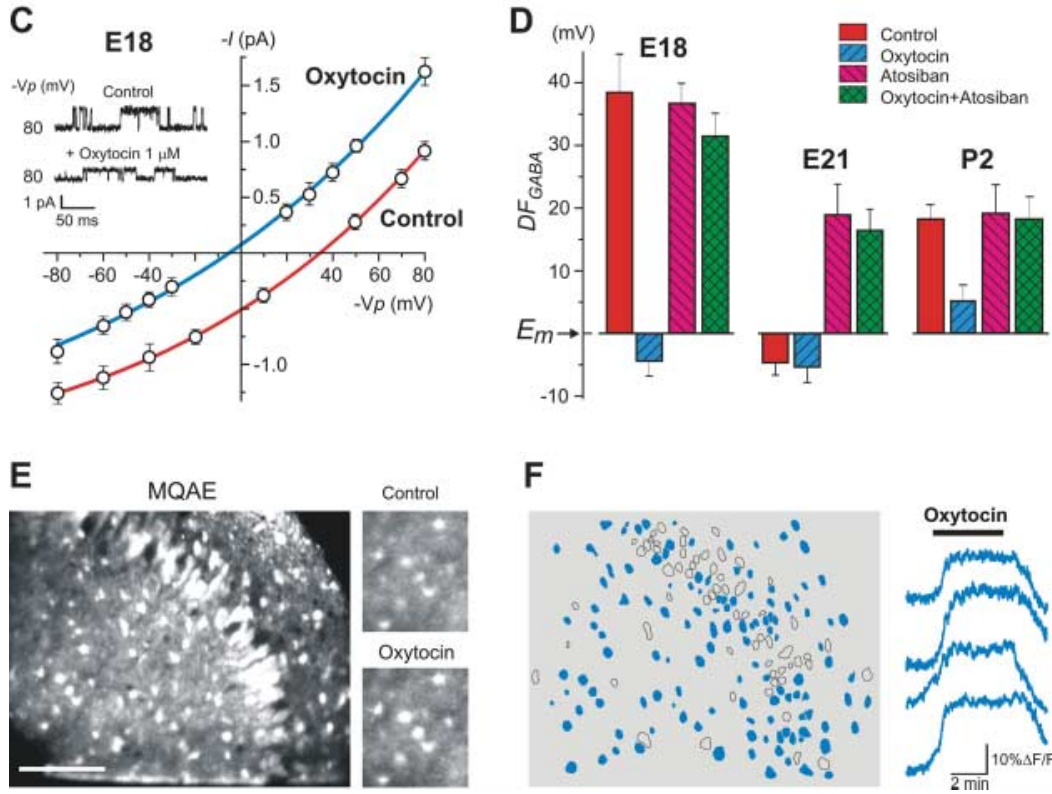

$\mathbf{F}$

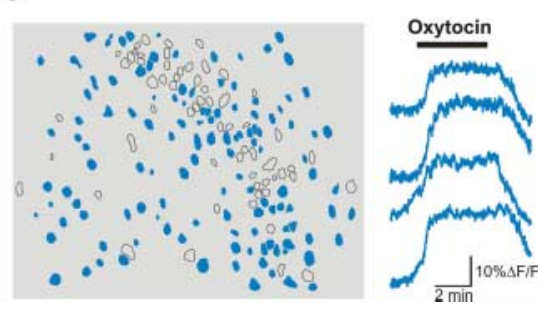

prepared from the fetuses intracardially perfused with atosiban $(5 \mu \mathrm{M} ; n=15)$ or from the fetuses whose mothers received SSR126768A (1 mg/kg; $n=19)$, AD onset was significantly accelerated to $44.1 \pm$ $1.1 \min (n=34 ; P<0.01)$. Bumetanide $(10 \mu \mathrm{M})$ applied in the presence of the oxytocin receptor antagonists delayed $\mathrm{AD}$ to the control values $(53.4 \pm$ 1.7 min; $n=18 ; P<0.01)$. Bumetanide $(10 \mu \mathrm{M})$

Fig. 3. Oxytocin causes a switch in $G A B A_{A}$ signaling from depolarizing to hyperpolarizing. (A) Oxytocin-receptor immunostaining of a PO rat hippocampus; (inset) CA3 pyramidal cells layer. Bars, $200 \mu \mathrm{m}$ and (inset) $20 \mu \mathrm{m}$. (B) Histograms of the proportion of cells excited by brief application of isoguvacine (Isog) in control and in the presence of oxytocin $(1 \mu \mathrm{M})$ at E18 and P2 ( $n=57$ cells). (C) I-V relationships of the currents through single $G_{A B A_{A}}$ channels recorded from two CA3 pyramidal cells at E18 in control and after addition of oxytocin $(1 \mu \mathrm{M})$. (D) Histograms of $D F_{\mathrm{GABA}}$ measured at E18, E21, and P2 in control conditions and in the presence of oxytocin $(1 \mu \mathrm{M})$, antagonist of oxytocin receptors atosiban ( 1 to $5 \mu \mathrm{M}$ ), and oxytocin plus atosiban ( $n=187$ cells). (E) Twophoton imaging of $\left[\mathrm{Cl}^{-}\right]_{\mathrm{i}}$ in $\mathrm{P} 4$ hippocampal slice loaded with $\mathrm{Cl}^{-}$indicator MQAE. Scale bar, $100 \mu \mathrm{m}$. (Right) $\left[\mathrm{Cl}^{-}\right]_{\mathrm{i}}$ fluorescence change produced by oxytocin application. The intensity of the fluorescence signal increases, and $\left[\mathrm{Cl}^{-}\right]_{i}$ decreases, in the illustrated region. (F) Automatically detected contours of the cells imaged in (E), indicating the distribution of cells in which oxytocin application produced a significant decrease in $\left[\mathrm{Cl}^{-}\right]_{\mathrm{i}}$ (blue filled contours). On the right, chloride fluorescence changes $(\Delta F / F)$ in four representative neurons. Time resolution is $100 \mathrm{~ms}$ per frame.
Fig. 4. Blockade of oxytocin receptors decreases fetal brain resistance to anoxia-aglycemia at birth. (A) Representative traces to illustrate the effects of anoxic-aglycemic solution on extracellular field potential recordings from E21 intact hippocampi. Arrows indicate terminal $A D$ that marks neuronal death. $A D$ occurs earlier in the presence of SSR126768A (middle trace). Addition of bumetanide $(10 \mu \mathrm{M})$ occludes the effects of the antagonist and restores the initial delay (bottom trace). (B) Summary plot of the onset of $A D$ in control, in the presence of the oxytocin receptors antagonists atosiban (AT, $5 \mu \mathrm{M}$, fetal intracardial perfusion and SSR126768A (1 mg/kg to the mother), and after further addition of bumetanide $(10 \mu \mathrm{M})$. Each circle corresponds to one hippocampus $(n=82$ intact hippocampi at E21). Error bars indicate SEM.
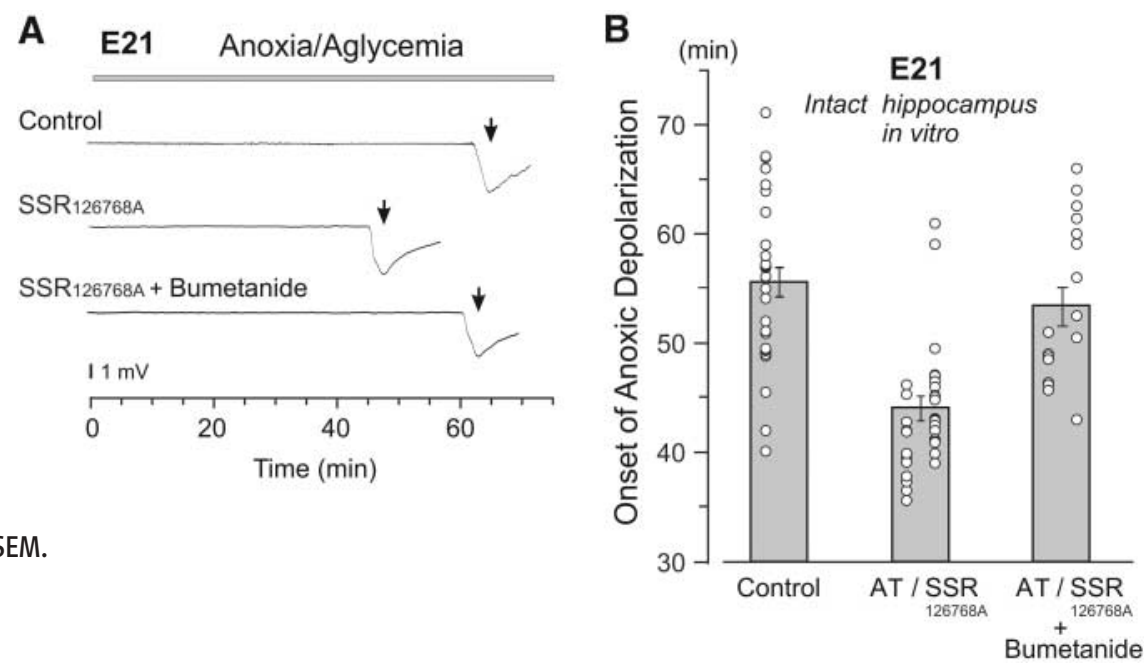
occluded the effects of the oxytocin receptor antagonists and restored the control delays (53.4 \pm $1.7 \mathrm{~min}, n=18 ; P<0.01)$. These data indicate that maternal oxytocin exerts a neuroprotective action on fetal neurons during parturition and that this action is likely due to a reduction of $[\mathrm{Cl}]_{i}$.

Our results suggest that oxytocin, in addition to its well-established role in labor and lactation and its multiple effects in the adult central nervous system (19-25), also exerts a powerful action on fetal neurons. This mechanism adds a previously unknown facet to the plasticity of GABA signaling via modulation of $\left[\mathrm{Cl}^{-}\right]_{\mathrm{i}}(4,33)$. The dual action produced by a single messenger in the mother and fetus enables a perfect timing for adaptation of fetal neurons to delivery.

\section{References and Notes}

1. J. J. Volpe, Neurology of the Newborn (Saunders, Philadelphia, ed. 4, 2000)

2. Y. Ben Ari, Nat. Rev. Neurosci. 3, 728 (2002).

3. D. F. Owens, A. R. Kriegstein, Nat. Rev. Neurosci. 3, 715 (2002).

4. J. A. Payne, C. Rivera, J. Voipio, K. Kaila, Trends Neurosci. 26, 199 (2003).

5. R. Tyzio et al., J. Neurosci. 19, 10372 (1999).
6. Y. Ben-Ari, E. Cherubini, R. Corradetti, J.-L. Gaïarsa, J. Physiol. 416, 303 (1989).

7. C. Rivera et al., Nature 397, 251 (1999)

8. D. F. Owens, L. H. Boyce, M. B. Davis, A. R. Kriegstein, ]. Neurosci. 16, 6414 (1996).

9. G. Chen, P. Q. Trombley, A. N. van den Pol, J. Physiol. 494, 451 (1996).

10. R. Serafini, A. Y. Valeyev, J. L. Barker, M. O. Poulter, J. Physiol. 488, 371 (1995).

11. Materials and methods are available as supporting material on Science Online.

12. X. Leinekugel, I. Medina, I. Khalilov, Y. Ben-Ari, R. Khazipov, Neuron 18, 243 (1997).

13. R. Tyzio et al., J. Neurophysiol. 90, 2964 (2003).

14. D. Maric et al., Eur. J. Neurosci. 10, 2532 (1998).

15. J. A. Connor, H. Y. Tseng, P. E. Hockberger, J. Neurosci. 7, 1384 (1987).

16. R. Yuste, L. C. Katz, Neuron 6, 333 (1991).

17. J. J. LoTurco, D. F. Owens, M. J. Heath, M. B. Davis, A. R. Kriegstein, Neuron 15, 1287 (1995).

18. O. Garaschuk, E. Hanse, A. Konnerth, J. Physiol. 507, 219 (1998).

19. G. Gimpl, F. Fahrenholz, Physiol. Rev. 81, 629 (2001).

20. A. Argiolas, G. L. Gessa, Neurosci. Biobehav. Rev. 15, 217 (1991).

21. M. Raggenbass, Prog. Neurobiol. 64, 307 (2001).

22. K. Tomizawa et al., Nat. Neurosci. 6, 384 (2003).

23. M. Kosfeld, M. Heinrichs, P. J. Zak, U. Fischbacher, E. Fehr, Nature 435, 673 (2005).

24. D. T. Theodosis et al., Mol. Cell. Neurosci. 31, 785 (2006).
25. D. Huber, P. Veinante, R. Stoop, Science 308, 245 (2005).

26. A. Malek, E. Blann, D. R. Mattison, ]. Matern. Fetal Med. 5, 245 (1996).

27. N. Marandi, A. Konnerth, O. Garaschuk, Pflugers Arch. 445, 357 (2002)

28. C. Serradeil-Le Gal et al., J. Pharmacol. Exp. Ther. 309, 414 (2004)

29. J. Yamada et al., J. Physiol. 557, 829 (2004).

30. V. I. Dzhala et al., Nat. Med. 11, 1205 (2005).

31. V. Dzhala, Y. Ben-Ari, R. Khazipov, Ann. Neurol. 48, 632 (2000).

32. P. Lipton, Physiol. Rev. 79, 1431 (1999).

33. H. Fiumelli, L. Cancedda, M. M. Poo, Neuron 48, 773 (2005).

34. We thank I. Jorquera, I. Chudotvorova, D. Diabira, and C. Pellegrino for technical assistance; K. Krnjevic, M. Milh, I. Medyna, J. L. Gaiarsa, A. Ivanov, and C. Hammond for helpful comments on the manuscript; and Sanofi-Synthelabs for the gift of SSR126768A. This work was supported by INSERM, Fondation pour la Recherche Médicale, L'Agence Nationale de la Recherche, Federation pour la Recherche sur le Cerveau and Rotary International, Conseil régional Provence-Alpes-Côte d'Azur, and European Community grant LSHB-CT-2004-503467.

\section{Supporting Online Material}

www.sciencemag.org/cgi/content/full/314/5806/1788/DC1

Materials and Methods

Figs. S1 to $\mathrm{S} 6$

References

31 July 2006; accepted 9 November 2006

10.1126/science. 1133212

\section{ATP Release Guides Neutrophil Chemotaxis via P2Y2 and A3 Receptors}

\begin{abstract}
Yu Chen, ${ }^{1 *}$ Ross Corriden, ${ }^{1,2 *}$ Yoshiaki Inoue, ${ }^{1}$ Linda Yip, ${ }^{1}$ Naoyuki Hashiguchi, ${ }^{1}$ Annelies Zinkernagel, ${ }^{4}$ Victor Nizet, ${ }^{4}$ Paul A. Insel, ${ }^{2,3}$ Wolfgang G. Junger ${ }^{1} \dagger$
\end{abstract}

Cells must amplify external signals to orient and migrate in chemotactic gradient fields. We find that human neutrophils release adenosine triphosphate (ATP) from the leading edge of the cell surface to amplify chemotactic signals and direct cell orientation by feedback through P2Y2 nucleotide receptors. Neutrophils rapidly hydrolyze released ATP to adenosine that then acts via A3-type adenosine receptors, which are recruited to the leading edge, to promote cell migration. Thus, ATP release and autocrine feedback through P2Y2 and A3 receptors provide signal amplification, controlling gradient sensing and migration of neutrophils.

$\mathrm{N}$ eutrophils are primary phagocytic cells with important roles in host defense and tissue repair. However, activated neutrophils damage host tissues and contribute to chronic inflammatory diseases, including rheumatoid arthritis, inflammatory bowel disease, and asthma (1). A key feature of neutrophils is their ability to detect and migrate to compromised tissues by following a concentration gradient of chemotactic substances released from microbial pathogens or injured cells.

${ }^{1}$ Department of Surgery, University of California San Diego, San Diego, CA 92103, USA. ${ }^{2}$ Department of Pharmacology, University of California San Diego, La Jolla, CA 92093, USA. ${ }^{3}$ Department of Medicine, University of California San Diego, La Jolla, CA 92093, USA. ${ }^{4}$ Department of Pediatrics, University of California San Diego, La Jolla, CA 92093, USA. *These authors contributed equally to this work. †To whom correspondence should be addressed. E-mail: wjunger@ucsd.edu
Neutrophils can respond to chemoattractant gradients that differ in concentration by as little as $1 \%$ across the length of the cell body (2). Chemotaxis must involve signal amplification because a strongly polarized distribution of intracellular signaltransduction components is observed even in shallow gradients. The mechanisms of signal amplification are unclear $(3,4)$. We identified the polarized release of adenosine triphosphate (ATP), the activation of $\mathrm{P} 2 \mathrm{Y} 2$ receptors, and the translocation and activation of A3 adenosine receptors as key mechanisms of signal amplification that control cell orientation and direct the migration of neutrophils.

Membrane deformation caused by mechanical or osmotic stress induces the release of cellular ATP from mammalian cells; however, detailed information on the underlying mechanisms is lacking $(5,6)$. Because cell migration also involves membrane deformation, we tested whether the stimulation of human neutrophils with the chemoattractant $N$-formyl-Met-Leu-Phe (FMLP) causes ATP release. Treatment of cells $\left(10^{7}\right.$ cells in $250 \mu \mathrm{l}$ of solution) with $100 \mathrm{nM}$ FMLP rapidly tripled extracellular ATP concentrations in bulk media (Fig. $1, \mathrm{~A}$ and $\mathrm{B}$ ) by inducing the release of $\sim 0.5 \%$ of their ATP pool. Concentrations of extracellular ATP and its hydrolytic products adenosine monophosphate (AMP) and adenosine peaked $5 \mathrm{~min}$ after FMLP stimulation; but while the concentration of ATP returned to basal levels after 15 min, AMP and adenosine concentrations remained $>5$-fold above baseline (Fig. 1B), which is consistent with the presence of ecto-adenosine triphosphatases (ecto-ATPases) $(7,8)$. Neutrophils completely hydrolyzed exogenous ATP $(5 \mu \mathrm{M})$ within 2 min after ATP addition, which suggests that they have potent ecto-ATPase activity (Fig. 1C).

Because membrane deformation occurs predominantly at the leading edge closest to the chemoattractant source, we hypothesized this region to be the principal site of ATP release. Fluorescent microscopy that was used to visualize ATP release [based on conversion of nicotinamide adenine dinucleotide phosphate $\left(\mathrm{NADP}^{+}\right)$to its reduced form NADPH] revealed that neutrophils discharge ATP within seconds after FMLP stimulation (Fig. $1 \mathrm{D}$ and movies $\mathrm{S} 1$ to $\mathrm{S} 3$ ), with ATP release highest near the cell membrane with the greatest degree of protrusion (Fig. 1D, inset).

Extracellular ATP and adenosine modulate neutrophil functions, including chemotaxis $(8,9)$. We tested the effect of apyrase, which hydrolyzes ATP, on chemotaxis in a trans-well system composed of upper wells with neutrophils and lower wells with $1 \mathrm{nM}$ FMLP separated by a filter with $3-\mu \mathrm{m}$ pores. Addition of apyrase to the upper wells reduced chemotaxis by nearly $100 \%$ (Fig. 2 A). 